\title{
Intention to start a business and entrepreneurship education programme: A pre- and post-program research design
}

\author{
Gentjan Çera \\ Department of Business Administration, Faculty of Management and Economics, Zlín, Czech \\ Republic and Department of Finance and Accounting, Faculty of Economics and Agribusiness, \\ Agricultural University of Tirana, Tirana, Albania, and
}

\section{Edmond Çera}

Department of Business Administration, Faculty of Management and Economics, Zlín, Czech Republic

\begin{abstract}
Purpose - The effect of a study programme in entrepreneurship on intention to start a business has not received adequate attention by researchers using a pre- and post-program research design. This paper seeks to find evidence of entrepreneurship education programme on entrepreneurial intention in the context of a post-communist transition county.

Design/methodology/approach - Coarsened exact matching (CEM) method is performed to achieve two similar groups: control (people who did not attend a study programme in entrepreneurship) and treated (those who attended) groups. Based on a set of covariates as identified in theory, 442 members were matched. Hypotheses developed in a pre- and post-program setting can be tested by employing the analysis of covariance (ANCOVA). Members' scores on intention to start a business before the programme was introduced, was used as the covariate in this analysis (pre-program).

Findings - The analysis confirm a significant difference between the two groups on entrepreneurial intention after the study programme in entrepreneurship was completed (post-program). Our results suggest that entrepreneurial intention is affected by entrepreneurship education programme.

Research limitations/implications - The study offers useful insights for universities and individuals running a business. Aiming better results in terms of entrepreneurship, university, industry and government should align their efforts following a triple helix model.

Originality/value - This work adds value to the entrepreneurship literature in the context of postcommunist transition country. Furthermore, it uses a rigor methodology that makes the comparison of control and treated groups possible.
\end{abstract}

Keywords: entrepreneurship education, entrepreneurial intention, impact assessment, coarsened exact matching, ANCOVA, Albania

\section{Introduction}

\subsection{Research problem}

Due to the fact that entrepreneurship reduces the unemployment rate and contribute to the economic growth, there is a constant concern among academics and policymakers on how to foster entrepreneurship. According to human capital theory (Becker, 1994), one established way of doing it is by enhancing individuals' skills and abilities in dealing with entrepreneurship.

There is a consensus among researchers regarding the linkage between entrepreneurship education programme, intention to start a business and start-ups (Durán-Sánchez et al., 2019; Kuratko, 2005; 
Rodrigues et al., 2012). The role of universities is considered very important in triggering the learning process and transferring the know-how to the individuals which in turn can promote the entrepreneurial activities (Audretsch, 2017). Of course, as Bosma et al. (2018) highlights, one can argue that the entrepreneurial activities are associated with economic growth. Also the capacity building in entrepreneurship is a continuous policy of engagement within the European Union (EU) (Packham et al., 2010). As per this policy, member countries should attach importance to enhancement of entrepreneurial competences, since these policies lead to start-up activity and job creation among young individuals (European Commission, 2012). This is supported by a global report on entrepreneurship which stresses out that economic advancement and reduction of unemployment can be attained through policies designed in fostering entrepreneurship (Herrington and Penny, 2017). As a result, this educational policy commitment regarding entrepreneurship education programmes has been instrumental in promoting business activity (Fayolle et al., 2006). Other authors (Kok et al., 2012), claimed that university graduates who attended a study programme in entrepreneurship are prone to exhibit more positive intention towards becoming an entrepreneur.

In the context of Albania, as a country which aspires to become a member of European Union, competitiveness has long been regarded as one of the most crucial issue. Its domestic market is "flooded" by imported products from EU countries due to the weak competition of domestic businesses. According to Global Competitiveness report, Albania was ranked as the $36^{\text {th }}$ in Europe (Schwab, 2018). In addition, this report implies that business competitiveness in Albanian is significantly low compared to other countries, especially to Germany. Researchers' findings converge in favour of the argument that a host of aspects are hard at work impacting the performance of businesses. In this regard, this paper sheds light on intention to start a business as a factor which can improve competitiveness. The most common question one may ask in this regard is how individuals can be motivated to start a business. Studies emphasise the important role that education programmes play in boosting business activity (Fereidouni and Masron, 2012; Martin et al., 2013). For this reason, policy aimed at start-ups should take into account instruments which foster the improvement of the students' education in entrepreneurship.

In case of Albania, the number of graduated students who considered starting and running their own business is very small. Official data obtained from the national agency of statistics in Albania show that the start-up rate has been dropping over the past three years (INSTAT, 2018a). At the moment, roughly eight out of ten students who attend public universities are not introduced to any type of program dealing and elaborating entrepreneurship skills. On the other hand, the unemployment rate has been reported very high among the Albanian young people. For the former age group, official data denote that almost one in four $(23 \%)$ individuals were unemployed, meanwhile for those over 30 years old it hovered around $9 \%$ in 2018. As it had been noted, study programmes in entrepreneurship leads to better opportunities at establishing and running a business and, as a consequence, cutting the unemployment rate among the graduates. As a result, developing entrepreneurship education programmes should be a priority for both university and policymakers.

\subsection{Motivation}

The majority of research related to intention to start a business has been rather limited to developed economies (Krueger et al., 2000). As a post-communist transition country, Albania has made progress towards acceding to EU. Despite our efforts, we have not been successful to pin down any study dealing with factors prompting intention to start a business in Albania. It should be underlined, however, that very few of studies (Dabic et al., 2012; Garo et al., 2015; Misoska et al., 2016; Palalic et al., 2016; Palalić et al., 2017) have been undertaken on intention to start a business in the Balkan countries, yet they do not fully elaborate the relationship between entrepreneurship education programme and intention to start a business. For this reason, there is a need to fill the gap in research over the relationship between intention to start a business and entrepreneurship education programme in post-communist transition Albania. 
While looking closer for the impact of entrepreneurship education programme on intention to start a business, there should be in place some rigor in the methodology being employed acting upon the suggestions of Fayolle and Liñán (2014), implying the comparison between treated group (individuals introduced to entrepreneurship education programme) and control group (those not being introduced). Regardless this approach has been exploited in this area of research (Iglesias-Sánchez et al., 2016; Johansen, 2013; Oosterbeek et al., 2010; Premand et al., 2016; Sánchez, 2011, 2013; Souitaris et al., 2007), along with the adoption of covariance analysis (Pedrini et al., 2017; Volery et al., 2013), we fall short of locating any paper that has implemented such an approach to attain a comparison between the two abovementioned groups. In the light of the pre and post-program setting the most crucial assumption is that these two groups should be as similar as possible (Stuart and Rubin, 2008). Due to our literature review, we figured out that in similar studies this important assumption has not been reported. The current paper contributes in this regard by applying CEM method that makes the comparison of treated and control groups possible.

\section{Literature review}

\subsection{Entrepreneurship education and intention to start a business}

The theory of planned behaviour (Ajzen, 1991), human capital theory (Becker, 1994), and entrepreneurial self-efficacy perspective (Chen et al., 1998) are the three main theories that researchers take into consideration when studying the relationship between entrepreneurship education programme and entrepreneurial intention. According to the theory introduced by Chen et al. (1998), it states that attitudes and intentions, including intention to start a business, can be motivated by study programme in entrepreneurship. Consequently, intention to start a business or to become an entrepreneur is influenced by entrepreneurship education programme.

Human capital obtained by education is considered by many researchers as one of the important factors of entrepreneurship (Martin et al., 2013; Van Der Sluis et al., 2008; Unger et al., 2011). A positive association was confirmed between the schooling years and start-up activity by graduated students (Lafuente and Vaillant, 2013; Millán et al., 2014). Moreover, Estrin et al. (2013) reported a positive influence of higher education on entrepreneur's growth aspiration. Chances to start own business are higher in cases when one holds a double or vocational diploma (Hietanen and Järvi, 2015; Joensuu-Salo et al., 2015) or if one has been graduated (Johansen, 2013). As a result, education and training for individuals should be taken in account as a driver of intention to start a business or to become an entrepreneur.

The role of entrepreneurship education programme in improving one's entrepreneurial skills has been a special focus of researchers (Dana, 1993, 2001). In generally, a study programme in entrepreneurship should provoke both intention to start a business and the individual's ability to turn ideas into a certain behave (action). According to Hahn et al. (2017), a study programme in entrepreneurship fuels the entrepreneurial learning. This finding is supported also by Sánchez $(2011,2013)$ who, through his studies, confirmed that individuals who attend a study programme in entrepreneurship improved their competencies and intention to start a business. After attending that programme, students perceived entrepreneurship as their future career (Stamboulis and Barlas, 2014).

The association between entrepreneurship education programme and intention to start a business is mainly concern of scholars in developed economies (Barba-Sánchez and Atienza-Sahuquillo, 2018; Martin et al., 2013; Wilson et al., 2007). Scholars who have studied this relationship have confirmed a positive influence of entrepreneurship education programme on intention to start a business (Bae et al., 2014; Maresch et al., 2016; Westhead and Solesvik, 2016). However, there are studies which contradict this conclusion. Entrialgo and Iglesias (2016) claimed that entrepreneurship education does not lead to intention to become an entrepreneur, based on their study's results. 


\subsection{The context of Albania}

The context is important for understanding the environment where the decision to engage in business activity are taken, including self-employed (Dana and Dana, 2005; Groenland and Dana, 2019). Fundamental changes have taken place in Albania since the change of the system from centralised to market-oriented economy, which occurred in the 1990s. This is the reason why Albania is called as a post-communist transition country. Albania, along with Balkan countries, aimed a quick transition by privatising stated-owned enterprises and liberalizing the prices. These countries hoped that entrepreneurs would adopted to the capitalism mindset (Ramadani and Dana, 2013). However, in the early stages of the transition, entrepreneurs did not know how to behave in the new environment (Dana, 1996). The entrepreneurial models imported from Western Europe and America were not giving the expected outcomes, because they were not adjusted to the context. Both, the institutional system and individuals were in transition. Hence, the individuals were facing with a lack of knowhow as they did not know how to behave in the new environment (Dana, 2011; Ramadani and Dana, 2013).

To survive and succeed in the transition stage, the individuals were needed to gain extra skills and knowledge dealing with the market-oriented economy. The policy instruments applied to foster entrepreneurship are different as compared to the early stage of the transition (Dana, 2011). However, the educational system still applies a not modern style of transferring knowledge to the individuals (Aaltio, 2008). In addition, it is hard to implement the entrepreneurial culture as it is in the Western countries, since different educational techniques are needed to be put in place. As job insecurity is growing, education should equip individuals with the appropriate skills and knowhow which are require to find a job. Both, skills and abilities, that one may say that are not that necessary in advance economies, might be valuable in the context of transition countries like Albania (Ramadani and Schneider, 2013).

Business activity is considered as one of the important domains in the economic development. This can be said even for transition countries like Albania (Çera et al., 2019). The published data do emphasise the vital role of small and medium-sized enterprises in contributing to the economy and reducing the unemployment rate. Hence, Albanian SMEs generate $68.3 \%$ of the value added in the economy, which is $12 \%$ more than the average of EU. In terms of employment, the SMEs employ $80.3 \%$ of the workforce in the private sector, which is $13.8 \%$ more than the average of EU (European Commission, 2019). As the result, it can be understood the importance of that SMEs have to the Albanian economy. However, the Albanian share of women entrepreneurs is the lowest among the neighbour countries (Ramadani, 2015). This evidence claims for more stress on policy-making in order to foster females to engage with business activity.

\subsection{Balancing the two groups}

A pre- and post-program research design requires two groups: control and treated groups. According to Trochim et al. (2016), a discussion on covariates that contributes on achieving the comparability of control and treated groups should be carried out. It should be underlined that covariates are linked to intention to start a business and not affected by treatment assignment (Stuart and Rubin, 2008).

The first covariate discussed here is 'age'. Individual's age is usually used as a covariate of the association of entrepreneurship education programme and intention to start a business. According to some studies, individuals at certain ages reflect higher attitudes to start a business or self-employment (Constant and Zimmermann, 2014; Goktan and Gupta, 2015; Kibler, 2013; van der Zwan et al., 2016). Alternatively, regarding the gender analysis, females reflected lower tendency to be involved in entrepreneurial activity (Çera et al., 2018; Díaz-García and Jiménez-Moreno, 2010; Engle et al., 2011; van der Zwan et al., 2016).

Furthermore, income and employment status are listed by scholars two other covariates which can influence intention to start a business. Studies have shown that the income is positively related with the entrepreneurial activity (Urbano et al., 2017; van der Zwan et al., 2016). Nonetheless, even the negative 
correlation between them is reported (Lee et al., 2011). Moreover, household income strengthens the effect on intention to start a business (Bhardwaj, 2018; Kibler, 2013). Of course, this can be typical in cases where individuals have strong relations with their relatives (Rantanen and Toikko, 2017). What an individual is actually performing influences intention to start a business (Haus et al., 2013). Students act and perform taking into consideration what their friends and/or relatives suggest (van Gelderen et al., 2008; Gohmann, 2012; Kalitanyi and Bbenkele, 2018), while non-students, like managers, do not dependent from them for the reason that they can take actions based on their experience or they are more confident on what are doing (Haus et al., 2013; Jaén and Liñán, 2013).

To be brief, intention to start a business or to become self-employed is affected by these covariates: age, gender, employment status and income. Accordingly, these covariates can used to balance treated and control groups.

\section{$3 \quad$ Research design and data}

\subsection{Research design}

Coarsened exact matching (CEM) method was used to create two similar groups: one includes individuals who have been introduced or attended a study programme on entrepreneurship (treated group) and the other comprises individuals who did not attend that programme (control or comparison group). A pre- and a post-program score for treated and control groups is required for this type of research design (Trochim et al., 2016). The term 'program' refers to a study programme on entrepreneurship offered by higher education institutions. It is any study programme of education which equip individuals with entrepreneurial skills and attitudes (Bae et al., 2014). We identified individuals in which group they belong by this question: Have you ever attended a subject in entrepreneurship? Individuals answered ' $N o$ ' were considered as members in control group, while those who selected 'Yes' were considered as treated members.

The pre- and post-program setting is included because entrepreneurial intention is "observed" in two moments: pre and post attending the study programme in entrepreneurship. Hence, the pre-program score denotes an individual's score on intention to become an entrepreneur before the study programme in entrepreneurship was introduced (Pre-IntBecEnt), while the post-program score represents one's score on intention to be entrepreneur after the attendance of that study programme (Post-IntBecEnt). Intention to become entrepreneur (entrepreneurial intention) was measured by a four-point scale item as with recent study (Çera et al., 2020; Mirjana et al., 2018; Sánchez-Escobedo et al., 2011; Shinnar et al., 2012; Veciana et al., 2005). Entrepreneurial intention was measured by this question: Have you ever thought of starting a business? The four possible responses were: 1-'No, never'; 2-'Yes, vaguely'; 3'Yes, seriously'; 4-'Yes, I have a definite plan to start my own business.'

To assess the impact of entrepreneurship education programme on individuals' intention to become entrepreneur, a comparison of control and treated groups should be done. This assumes that two groups are comparable. To ensure this, CEM method were used. The aim of CEM is to 'balance' the distribution of covariates in both treated and control groups. CEM matches members from control group with treated ones (Iacus et al., 2012). Its principle regarding continuous covariates is that the latter should be grouped under wider categories for matching, known as coarsening. Variables that can affect the level of the outcome variable. Driven by theory, these covariates are gender (male/female), age (scale variable), income (ordinal variable) and employment status (nominal variable).

[Table 1 about here]

CEM method matched 173 treated members with 269 from control group (see Table 1). So, the total number of matched were 442 members. The multivariate imbalance measure statistic reports the 'goodfit' of matching. According to Iacus et al. (2011), if it is below 20\% it shows that CEM did a considerable balancing of covariates distribution in control and treated groups. For our sample, this 
statistics was $18.7 \%$. So, $81.3 \%$ of the density of the histograms of two groups overlapped. By way of argument, after applying the matching method, control and treated groups were similar. As a result, control and treated groups can be compare and its findings are not misleading.

\subsection{Data}

A survey in individual level was administrated by a company operating in market research called IDRA. Data were collected from the eight main urban regions in Albania during the first months of 2018. A questionnaire was design and filled in by individuals selected by using satisfaction procedures such as region population and gender profile. Even though almost one thousand questionnaires were filled in only half of them (528 respondents) were valid for the current study.

[Table 2 about here]

Table 2 shows the sample profile by gender and region before and after matching was applied. It demonstrates the actual distribution of students in higher education in Albania (INSTAT, 2018b).

\subsection{Method}

To test the impact of entrepreneurship education program on individual's intention to become an entrepreneur, a one-way between subjects analysis of covariance (ANCOVA) is performed. This method is the appropriate one that deals with issues designed in a pre and post-program setting (Tabachnick and Fidell, 2013). The sensitivity of the test of main effects and interactions is increased by this method by reducing the error term. This decrease in the error term is likely to occur due to the relationship between the covariate and the dependent variable. In current research, the variable measuring the one's intention to become an entrepreneur before introducing with entrepreneurship education programme was used as covariate in ANCOVA. Before performing ANCOVA, preliminary checks should be done, in particular concerning the assumptions. Firstly, the error variance of the dependent variable should be equal across two groups. This can be checked by the Levene's test of equality of error variances. It revealed that insignificance, $F(1,440)=1.670, p=0.197$.

Next assumption is that the covariate (Pre-IntBecEnt) should be statistically no different across the levels of program. It can be checked by employing a one-way analysis of variance (ANOVA). Table 3 summarizes its results. It was found that this assumption was satisfied $(p>0.05), F(1,440)=3.299, p$ $=0.07$.

[Table 3 about here]

The final assumption is related to the homogeneity of regression slopes. It requires that the relationship between the dependent variable (Post-IntBecEnt) and covariate (Pre-IntBecEnt) for both treated and control groups should be the same. It can be tested by performing not a full factorial one-way ANCOVA with Post-IntBecEnt as dependent variable and Program as independent variable including PreIntBecEnt as covariate and an interaction of Program with Pre-IntBecEnt as illustrated in Table 4. In the current research, this interaction was insignificant, thereby, not risking the violation of the homogeneity of regression slopes, $F(1,440)=2.342, p=0.127$. As a result, these three assumptions were not violated, so a one-way ANCOVA can be performed and its findings are not misleading.

[Table 4 about here]

Scholars are interested not only at the significance of a relationship but also at its size of the effect. ANCOVA performed in SPSS version 23 along with other statistics provides partial eta square (partial $\left.\eta^{2}\right)$. However, academics do prefer more eta square $\left(\eta^{2}\right)$ statistic as an effect size measure in this research 
designs. Cohen's (1988) effect size benchmarks were considered: small $=0.01$, medium $=0.06$, and large $=0.14$.

\section{Results}

Before giving the results of ANCOVA, we present in Table 5 the number of participants, mean and standard deviation of Pre-IntBecEnt and Post-IntBecEnt for two samples: before and after applying CEM methods. Applying CEM did not lead to significant differences in mean and standard deviation of intention to become an entrepreneur (for Pre-IntBecEnt: from 0.865 to 0.859, for Post-IntBecEnt: from 0.995 to 0.99 ). A difference in means of intention to become an entrepreneur can be detected: from control group to treated group (for Pre-IntBecEnt: 1.565 vs 1.717, for Post-IntBecEnt: 1.807 vs 2.202) and from before and after introducing the program (for control group: from 1.565 to 1.807 , for treated group: from 1.717 to 2.202). If these differences are found to be significant, then our evidence support the impact of entrepreneurship education programme on intention to become an entrepreneur.

[Table 5 about here]

A one-way between subjects ANCOVA was performed to investigate the impact of entrepreneurship education programme on intention to become an entrepreneur. The independent variable was the Program (introduced and attended a study program in entrepreneurship: Yes/No), and the dependent variable Post-IntBecEnt. Individuals' scores on intention to become an entrepreneur before the program was introduced (Pre-IntBecEnt) was used as the covariate in this analysis. The results of the one-way are shown in Table 6.

Preliminary checks were done to ensure that there was no violation of the ANCOVA's assumptions (refer to Table 3 and Table 4). After adjusting for pre-program score on intention to become an entrepreneur (Pre-IntBecEnt), there was a statistical significant difference between the control and treated groups (those who have attended a study program in entrepreneurship and those who have not) on Post-IntBecEnt. Referring to the values of eta squares, the effect size of this impact was small, $F(1$, $439)=16.225, p<0.001, \eta^{2}=0.018$. This finding support the impact of entrepreneurship education programme on intention to become an entrepreneur.

Additionally, ANCOVA revealed a statistical significant relationship between intention to become an entrepreneur before the study programme was introduced (Pre-IntBecEnt) and after finishing it (PostIntBecEnt), $F(1,439)=406.974, p<0.001, \eta^{2}=0.463$. Further to this, there was a large effect size in the relationship between them as showed by an eta squared greater than 0.14 . It shows that $46.3 \%$ of Post-IntBecEnt was attributable to the Pre-IntBecEnt variable.

[Table 6 about here]

Figure 1 illustrates differences in the estimated marginal means of Post-IntBecEnt for both groups: individuals that have attended an entrepreneurship education programme and those who have not. In the current research, the estimated marginal means represent the adjusted means on the dependent variable for control and treated groups. As Tabachnick and Fidell (2013) explain, the term 'adjusted' is used in the context that the influence of the covariate (Pre_IntBecEnt) has been removed. As demonstrated by the figure, it is clear that individuals who attended a study programme in entrepreneurship reflected higher intention to start a business. The estimated marginal means of intention to become an entrepreneur after attending the entrepreneurial education programme was 2.13, whereas for those who did not attend it this mean was 1.853 . The difference between them is a considerable one $(0.277=2.13-1.853)$ since the values of this variable range from 1 to 4 . 
[Figure 1 about here]

\section{Discussion}

This research found evidence that attending a study programme in entrepreneurship offered by universities positively impacts individuals' intention to start a business. Our result goes in the same line with studies administrated in developed countries (Hahn et al., 2017; Iglesias-Sánchez et al., 2016; Sánchez, 2013). Somehow, we addressed what Krueger et al. (2000) claimed concerning the limited papers conducted in developing countries. Our paper went far than that by focusing at a post-communist transition country like Albania. In this regard, this paper adds value to entrepreneurship literature.

The study's findings are useful insights for universities and individuals running a business. Aiming better results in terms of entrepreneurship, Albanian educational system should include entrepreneurship education programme even to non-economic study programmes. A strand of literature in this field has been focused at the intention to start a business for individuals who have been graduated in non-economic fields (Åstebro et al., 2012; Barba-Sánchez and Atienza-Sahuquillo, 2018; Maresch et al., 2016; Westhead and Solesvik, 2016). Additionally, extra efforts should be put to address the need of establishing connections with firms operating in different sectors, which is pointed out even by the European Commission (2016). The Albanian government has started to adopt and implement an action plan (European Commission, 2017) on the basis of a triple helix model: universities, government, and business.

From a wider perspective, as scholars have climbed, higher educational institutions and government should find the best ways in achieving better results from the educational system and a friendly business climate (Brixiova and Égert, 2017; Ratten, 2017). The latter can lead to increasing the number of skilled people in dealing with different issues in entrepreneurship. Both abovementioned authorities should pay attention to drafting curricula and policies aimed at equipping individuals with skills and capabilities in entrepreneurial activities. Henceforth, policies focused at entrepreneurship and educational system, in particular higher education, should be harmonised (Millán et al., 2014). Firms in collaboration with universities contribute in this regard by enhancing individual's skills and ability for entrepreneurial activity. This can be reached by establishing a friendly environment for graduate students to benefit from the internship programs offered by firms (Dvorský et al., 2019; Filippetti and Savona, 2017; Palalić et al., 2019) and government, on the basis of the triple helix model (Feola et al., 2019; Kim et al., 2012).

\section{Concluding remaks}

The aim of this paper was to investigate whether entrepreneurship education programme impact intention to start a business or not in the context of post-communist transition Albania. Its contribution is seen important in providing evidence for this relationship for a region like the Balkans characterized by lack of studies in this field. Beside this, our study used a solid and rigor methodology in dealing with impact assessment. Since we did not found any article that has reported that two groups were similar, we modestly pretend that we are among the firsts scholars that used CEM method to balance the distribution of covariates between control and treated group by ensuring the comparability of two groups.

The current research contributes to the entrepreneurship literature by offering insights from a postcommunist transition context. The study's findings do emphasise the role of entrepreneurship education program in fostering individuals to engage in start-ups activity. This insight claims for more attention to the curricula design in order to leverage the start-up rate even in transition countries like Albania.

\section{References}

Aaltio, I. (2008), "Management education as an identity construction: the case of Estonia and its transition economy background", International Journal of Entrepreneurship and Small Business, 
Vol. 5 No. 1, pp. 83-99.

Ajzen, I. (1991), "The theory of planned behavior", Organizational Behavior and Human Decision Processes, Vol. 50 No. 2, pp. 179-211.

Åstebro, T., Bazzazian, N. and Braguinsky, S. (2012), "Startups by recent university graduates and their faculty: Implications for university entrepreneurship policy", Research Policy, North-Holland, Vol. 41 No. 4, pp. 663-677.

Audretsch, D.B. (2017), "Entrepreneurship and universities", International Journal of Entrepreneurship and Small Business, Vol. 31 No. 1, p. 4.

Bae, T.J., Qian, S., Miao, C. and Fiet, J.O. (2014), "The Relationship Between Entrepreneurship Education and Entrepreneurial Intentions: A Meta-Analytic Review", Entrepreneurship Theory and Practice, Vol. 38 No. 2, pp. 217-254.

Barba-Sánchez, V. and Atienza-Sahuquillo, C. (2018), "Entrepreneurial intention among engineering students: The role of entrepreneurship education", European Research on Management and Business Economics, Vol. 24 No. 1, pp. 53-61.

Becker, G.S. (1994), "Human capital revisited", Human Capital: A Theoretical and Empirical Analysis with Special Reference to Education, 3rd ed., The university of Chicago press, Chicago, pp. 1528.

Bhardwaj, B.R. (2018), "Can education empower women through entrepreneurial marketing: A model for upliftment of community services", Journal of Enterprising Communities, Emerald Group Publishing Ltd., Vol. 12 No. 1, pp. 19-31.

Bosma, N., Content, J., Sanders, M. and Stam, E. (2018), "Institutions, entrepreneurship, and economic growth in Europe", Small Business Economics, Vol. 51 No. 2, pp. 483-499.

Brixiova, Z. and Égert, B. (2017), "Entrepreneurship, institutions and skills in low-income countries", Economic Modelling, North-Holland, Vol. 67, pp. 381-391.

Çera, G., Breckova, P., Çera, E. and Rozsa, Z. (2019), "The Effect of Business Enabling Policies, Tax Treatment, Corruption and Political Connections on Business Climate", Acta Polytechnica Hungarica, Vol. 16 No. 4, pp. 113-132.

Çera, G., Cepel, M., Zakutna, S. and Rozsa, Z. (2018), "Gender differences in perception of the university education quality as applied to entrepreneurial intention", Journal of International Studies, Vol. 11 No. 3, pp. 147-160.

Çera, G., Mlouk, A., Çera, E. and Shumeli, A. (2020), "The Impact of Entrepreneurship Education on Entrepreneurial Intention. A Quasi-Experimental Research Design", Journal of Competitiveness, Vol. 12 No. 1, pp. 39-56.

Chen, C.C., Greene, P.G. and Crick, A. (1998), "Does entrepreneurial self-efficacy distinguish entrepreneurs from managers?", Journal of Business Venturing, Vol. 13 No. 4, pp. 295-316.

Cohen, J. (1988), Statistical Power Analysis for the Behavioral Sciences, 2nd ed., L. Erlbaum Associates, United States of America.

Constant, A.F. and Zimmermann, K.F. (2014), "Self-employment against employment or unemployment: Markov transitions across the business cycle", Eurasian Business Review, Springer International Publishing, Vol. 4 No. 1, pp. 51-87.

Dabic, M., Daim, T., Bayraktaroglu, E., Novak, I. and Basic, M. (2012), "Exploring gender differences in attitudes of university students towards entrepreneurship", International Journal of Gender and Entrepreneurship, Emerald Group Publishing Limited, Vol. 4 No. 3, pp. 316-336.

Dana, L.-P. (1993), “An international survey of entrepreneurship education”, Journal of Enterprising Culture, World Scientific Pub Co Pte Lt, Vol. 01 No. 01, pp. 67-92.

Dana, L.-P. (2001), "The education and training of entrepreneurs in Asia", Education + Training, Vol. 43 No. 8-9, pp. 405-416.

Dana, L.P. (1996), "Albania in the twilight zone: The perseritje model and its impact on small business", Journal of Small Business Management, Vol. 34 No. 1, pp. 64-70.

Dana, L.P. (2011), When Economies Change Hands: A Survey of Entrepreneurship in the Emerging Markets of Europe from the Balkans to the Baltic States, Routledge, New York, NY, available at: https://www.routledge.com/When-Economies-Change-Hands-A-Survey-of-Entrepreneurship-inthe-Emerging/Dana/p/book/9780203049013 (accessed 11 February 2019).

Dana, L.P. and Dana, T.E. (2005), "Expanding the scope of methodologies used in entrepreneurship research", International Journal of Entrepreneurship and Small Business, Vol. 2 No. 1, pp. 79- 
88.

Díaz-García, M.C. and Jiménez-Moreno, J. (2010), "Entrepreneurial intention: the role of gender", International Entrepreneurship and Management Journal, Springer US, Vol. 6 No. 3, pp. 261283.

Durán-Sánchez, A., Del Río-Rama, M. de la C., Álvarez-García, J. and García-Vélez, D.F. (2019), "Mapping of scientific coverage on education for Entrepreneurship in Higher Education", Journal of Enterprising Communities, Emerald Group Publishing Ltd., Vol. 13 No. 1-2, pp. 84-104.

Dvorský, J., Petráková, Z., Çera, G. and Folvarčna, A. (2019), "Important factors for the entrepreneurship in Central Europe”, Innovative Marketing, Vol. 15 No. 2, pp. 71-83.

Engle, R.L., Schlaegel, C. and Dimitriadi, N. (2011), "Institutions and entrepreneurial intent: A crosscountry study", Journal of Developmental Entrepreneurship, World Scientific Publishing Company, Vol. 16 No. 02, pp. 227-250.

Entrialgo, M. and Iglesias, V. (2016), "The moderating role of entrepreneurship education on the antecedents of entrepreneurial intention", International Entrepreneurship and Management Journal, Springer US, Vol. 12 No. 4, pp. 1209-1232.

Estrin, S., Korosteleva, J. and Mickiewicz, T. (2013), "Which institutions encourage entrepreneurial growth aspirations?", Journal of Business Venturing, Elsevier, Vol. 28 No. 4, pp. 564-580.

European Commission. (2012), Rethinking Education: Investing in Skills for Better Socio-Economic Outcomes, Strasbourg, available at: https://eur-lex.europa.eu/legalcontent/EN/TXT/?uri=CELEX:52012DC0669 (accessed 29 April 2018).

European Commission. (2016), Commission Staff Working Document Albania 2016 Report, European Commission, Brussel, available at: https://ec.europa.eu/neighbourhoodenlargement/sites/near/files/pdf/key_documents/2016/20161109_report_albania.pdf (accessed 6 October 2017).

European Commission. (2017), European Neighbourhood Policy and Enlargement Negotiations: 2017 SBA Fact Sheet Albania, Brussel, available at: https://ec.europa.eu/neighbourhoodenlargement/sites/near/files/albania_sba_fs_2017.pdf (accessed 30 September 2018).

European Commission. (2019), 2019 SBA Fact Sheet Albania, Brussels, available at: https://ec.europa.eu/growth/smes/business-friendly-environment/performance-review/ (accessed 4 January 2020).

Fayolle, A., Gailly, B. and Lassas-Clerc, N. (2006), "Assessing the impact of entrepreneurship education programmes: a new methodology", Journal of European Industrial Training, Emerald Group Publishing Limited, Vol. 30 No. 9, pp. 701-720.

Fayolle, A. and Liñán, F. (2014), "The future of research on entrepreneurial intentions", Journal of Business Research, Elsevier, Vol. 67 No. 5, pp. 663-666.

Feola, R., Vesci, M., Botti, A. and Parente, R. (2019), "The Determinants of Entrepreneurial Intention of Young Researchers: Combining the Theory of Planned Behavior with the Triple Helix Model", Journal of Small Business Management, Vol. 57 No. 4, pp. 1424-1443.

Fereidouni, H.G. and Masron, T.A. (2012), "Governance Matters and Entrepreneurial Activities", Thunderbird International Business Review, Wiley-Blackwell, Vol. 54 No. 5, pp. 701-712.

Filippetti, A. and Savona, M. (2017), "University-industry linkages and academic engagements: individual behaviours and firms' barriers. Introduction to the special section", The Journal of Technology Transfer, Springer US, Vol. 42 No. 4, pp. 719-729.

Garo, E., Kume, V. and Basho, S. (2015), "Determinants of Entrepreneurial Intention among University Students: Case of Albania", Multidisciplinary Journal for Education, Social and Technological Sciences, Vol. 2 No. 2, p. 176.

van Gelderen, M., Brand, M., van Praag, M., Bodewes, W., Poutsma, E. and van Gils, A. (2008), "Explaining entrepreneurial intentions by means of the theory of planned behaviour", Career Development International, Vol. 13 No. 6, pp. 538-559.

Gohmann, S.F. (2012), "Institutions, Latent Entrepreneurship, and Self-Employment: An International Comparison", Entrepreneurship Theory and Practice, SAGE PublicationsSage CA: Los Angeles, CA, Vol. 36 No. 2, pp. 295-321.

Goktan, A.B. and Gupta, V.K. (2015), "Sex, gender, and individual entrepreneurial orientation: evidence from four countries", International Entrepreneurship and Management Journal, Springer US, Vol. 11 No. 1, pp. 95-112. 
Groenland, E. and Dana, L.-P. (2019), Qualitative Methodologies and Data Collection Methods, Vol. 01, WORLD SCIENTIFIC, available at:https://doi.org/10.1142/11449.

Hahn, D., Minola, T., Van Gils, A. and Huybrechts, J. (2017), "Entrepreneurial education and learning at universities: exploring multilevel contingencies", Entrepreneurship \& Regional Development, Routledge, Vol. 29 No. 9-10, pp. 945-974.

Haus, I., Steinmetz, H., Isidor, R. and Kabst, R. (2013), "Gender effects on entrepreneurial intention: a meta-analytical structural equation model", International Journal of Gender and Entrepreneurship, Emerald Group Publishing Limited, Vol. 5 No. 2, pp. 130-156.

Herrington, M. and Penny, K. (2017), Global Entrepreneurship Monitor Global Report 2016/2017, available at: http://www.gemconsortium.org/report/49812 (accessed 20 April 2018).

Hietanen, L. and Järvi, T. (2015), "Contextualizing entrepreneurial learning in basic and vocational education", Journal of Enterprising Communities, Emerald Group Publishing Ltd., Vol. 9 No. 1, pp. 45-60.

Iacus, S.M., King, G. and Porro, G. (2011), "Multivariate Matching Methods That Are Monotonic Imbalance Bounding", Journal of the American Statistical Association, Taylor \& Francis, Vol. 106 No. 493, pp. 345-361.

Iacus, S.M., King, G. and Porro, G. (2012), "Causal Inference without Balance Checking: Coarsened Exact Matching”, Political Analysis, Cambridge University Press, Vol. 20 No. 01, pp. 1-24.

Iglesias-Sánchez, P.P., Jambrino-Maldonado, C., Velasco, A.P. and Kokash, H. (2016), "Impact of entrepreneurship programmes on university students", Education + Training, Emerald Group Publishing Limited, Vol. 58 No. 2, pp. 209-228.

INSTAT. (2018a), “Active enterprises, New registration and Birth rate”, Institute of Statistics, available at:

http://databaza.instat.gov.al/pxweb/en/DST/START_BR_BR0/BR0019/table/tableViewLayou $\mathrm{t} 2 /$ ?rxid=20e233db-95ca-402a-b227-5dbe36feae17 (accessed 3 January 2019).

INSTAT. (2018b), "Labour Market and Education, Education", Institute of Statistics, available at: http://www.instat.gov.al/en/themes/labour-market-and-education/education/\#tab3 (accessed 3 January 2019).

Jaén, I. and Liñán, F. (2013), "Work values in a changing economic environment: the role of entrepreneurial capital", edited by Jose-Luis Hervas-Oliver, P.International Journal of Manpower, Emerald Group Publishing Limited, Vol. 34 No. 8, pp. 939-960.

Joensuu-Salo, S., Varamäki, E. and Viljamaa, A. (2015), "Beyond intentions - what makes a student start a firm?”, Education + Training, Vol. 57 No. 8/9, pp. 853-873.

Johansen, V. (2013), "Entrepreneurship education and start-up activity: a gender perspective", International Journal of Gender and Entrepreneurship, Vol. 5 No. 2, pp. 216-231.

Kalitanyi, V. and Bbenkele, E. (2018), "Cultural values as determinants of entrepreneurial intentions among university students in Cape Town-South Africa", Journal of Enterprising Communities, Emerald Group Publishing Ltd., Vol. 12 No. 4, pp. 437-453.

Kibler, E. (2013), "Formation of entrepreneurial intentions in a regional context", Entrepreneurship \& Regional Development, Vol. 25 No. 3-4, pp. 293-323.

Kim, Y., Kim, W. and Yang, T. (2012), "The effect of the triple helix system and habitat on regional entrepreneurship: Empirical evidence from the U.S.”, Research Policy, Vol. 41 No. 1, pp. 154166.

Kok, J.D., Snijders, J.A., Smit, L., Der, B.V. and Linden. (2012), Effects and Impact of Entrepreneurship Programmes in Higher Education, Brussels, available at: https://www.semanticscholar.org/paper/Effects-and-impact-of-entrepreneurship-programmesKok-Snijders/d0b6f58d699bc62ea5748d0ae70843bdbfff424f (accessed 17 December 2018).

Krueger, N.F., Reilly, M.D. and Carsrud, A.L. (2000), "Competing models of entrepreneurial intentions", Journal of Business Venturing, Elsevier, Vol. 15 No. 5-6, pp. 411-432.

Kuratko, D.F. (2005), "The Emergence of Entrepreneurship Education: Development, Trends, and Challenges", Entrepreneurship Theory and Practice, Wiley/Blackwell (10.1111), Vol. 29 No. 5, pp. 577-598.

Lafuente, E.M. and Vaillant, Y. (2013), "Age driven influence of role-models on entrepreneurship in a transition economy”, Journal of Small Business and Enterprise Development, Vol. 20 No. 1, pp. $181-203$. 
Lee, L., Wong, P.K., Foo, M. Der and Leung, A. (2011), "Entrepreneurial intentions: The influence of organizational and individual factors", Journal of Business Venturing, Elsevier, Vol. 26 No. 1, pp. 124-136.

Maresch, D., Harms, R., Kailer, N. and Wimmer-Wurm, B. (2016), "The impact of entrepreneurship education on the entrepreneurial intention of students in science and engineering versus business studies university programs", Technological Forecasting and Social Change, North-Holland, Vol. 104, pp. 172-179.

Martin, B.C., McNally, J.J. and Kay, M.J. (2013), "Examining the formation of human capital in entrepreneurship: A meta-analysis of entrepreneurship education outcomes", Journal of Business Venturing, Vol. 28 No. 2, pp. 211-224.

Millán, J.M., Congregado, E., Román, C., van Praag, M. and van Stel, A. (2014), "The value of an educated population for an individual's entrepreneurship success", Journal of Business Venturing, Vol. 29 No. 5, pp. 612-632.

Mirjana, P.B., Ana, A. and Marjana, M.-S. (2018), "Examining determinants of entrepreneurial intentions in Slovenia: applying the theory of planned behaviour and an innovative cognitive style", Economic Research-Ekonomska Istraživanja, Routledge, Vol. 31 No. 1, pp. 1453-1471.

Misoska, A.T., Dimitrova, M. and Mrsik, J. (2016), "Drivers of entrepreneurial intentions among business students in Macedonia”, Economic Research-Ekonomska Istraživanja, Vol. 29 No. 1, pp. $1062-1074$.

Oosterbeek, H., van Praag, M. and Ijsselstein, A. (2010), “The impact of entrepreneurship education on entrepreneurship skills and motivation", European Economic Review, North-Holland, Vol. 54 No. 3 , pp. 442-454.

Packham, G., Jones, P., Miller, C., Pickernell, D. and Thomas, B. (2010), "Attitudes towards entrepreneurship education: a comparative analysis", edited by Matlay, H.Education + Training, Vol. 52 No. 8/9, pp. 568-586.

Palalic, R., Durakovic, B., Brankovic, A. and Ridic, O. (2016), "Students' entrepreneurial orientation intention, business environment and networking: Insights from Bosnia and Herzegovina", International Journal of Foresight and Innovation Policy, Inderscience Enterprises Ltd., Vol. 11 No. 4, pp. 240-255.

Palalić, R., Ramadani, V., Đilović, A., Dizdarević, A. and Ratten, V. (2017), "Entrepreneurial intentions of university students: a case-based study", Journal of Enterprising Communities, Emerald Group Publishing Ltd., Vol. 11 No. 3, pp. 393-413.

Palalić, R., Ramadani, V., Welsh, D.H.B., Dizdarević, A. and Đilović, A. (2019), "Impact of networking and business environment on student leadership styles", International Entrepreneurship and Management Journal, Springer, pp. 1-29.

Pedrini, M., Langella, V. and Molteni, M. (2017), "Do entrepreneurial education programs impact the antecedents of entrepreneurial intention?: An analysis of an entrepreneurship MBA in Ghana", Journal of Enterprising Communities, Emerald Group Publishing Ltd., Vol. 11 No. 3, pp. 373392.

Premand, P., Brodmann, S., Almeida, R., Grun, R. and Barouni, M. (2016), "Entrepreneurship Education and Entry into Self-Employment Among University Graduates", World Development, Pergamon, Vol. 77, pp. 311-327.

Ramadani, V. (2015), "The woman entrepreneur in Albania: An exploratory study on motivation, problems and success factors", Journal of Balkan and Near Eastern Studies, Routledge, Vol. 17 No. 2, pp. 204-221.

Ramadani, V. and Dana, L.-P. (2013), "The State of Entrepreneurship in the Balkans: Evidence from Selected Countries", Entrepreneurship in the Balkans, Springer Berlin Heidelberg, Berlin, Heidelberg, pp. 217-250.

Ramadani, V. and Schneider, R.C. (Eds.). (2013), Entrepreneurship in the Balkans, Springer Berlin Heidelberg, Berlin, Heidelberg, available at:https://doi.org/10.1007/978-3-642-36577-5.

Rantanen, T. and Toikko, T. (2017), "The relationship between individualism and entrepreneurial intention - a Finnish perspective", Journal of Enterprising Communities, Emerald Group Publishing Ltd., Vol. 11 No. 2, pp. 289-306.

Ratten, V. (2017), "Entrepreneurial universities: the role of communities, people and places", Journal of Enterprising Communities, Emerald Group Publishing Ltd., Vol. 11 No. 3, pp. 310-315. 
Rodrigues, G.R., Dinis, A., Do, A., Ferreira, J. and Raposo, M. (2012), "The Effect of an Entrepreneurial Training Programme on Entrepreneurial Traits and Intention of Secondary Students", in Burger-Helmchen, T. (Ed.), Entrepreneurship - Born, Made and Educated, InTech, Rijeka, Croatia, pp. 77-92.

Sánchez-Escobedo, M. de la C., Díaz-Casero, J.C., Hernández-Mogollón, R. and Postigo-Jiménez, M.V. (2011), "Perceptions and attitudes towards entrepreneurship. An analysis of gender among university students", International Entrepreneurship and Management Journal, Springer US, Vol. 7 No. 4, pp. 443-463.

Sánchez, J.C. (2011), "University training for entrepreneurial competencies: Its impact on intention of venture creation", International Entrepreneurship and Management Journal, Springer US, Vol. 7 No. 2, pp. 239-254.

Sánchez, J.C. (2013), "The Impact of an Entrepreneurship Education Program on Entrepreneurial Competencies and Intention", Journal of Small Business Management, John Wiley \& Sons, Ltd (10.1111), Vol. 51 No. 3, pp. 447-465.

Schwab, K. (2018), The Global Competitiveness Report 2018, Geneva, Switzerland, available at: https://www.weforum.org/reports/the-global-competitveness-report-2018 (accessed 3 January 2019).

Shinnar, R.S., Giacomin, O. and Janssen, F. (2012), "Entrepreneurial Perceptions and Intentions: The Role of Gender and Culture", Entrepreneurship Theory and Practice, Vol. 36 No. 3, pp. 465-493.

Van Der Sluis, J., Van Praag, M. and Vijverberg, W. (2008), "Education and entrepreneurship selection and performance: a review of the empirical literature", Journal of Economic Surveys, Vol. 22 No. 5, pp. 795-841.

Souitaris, V., Zerbinati, S. and Al-Laham, A. (2007), "Do entrepreneurship programmes raise entrepreneurial intention of science and engineering students? The effect of learning, inspiration and resources", Journal of Business Venturing, Elsevier, Vol. 22 No. 4, pp. 566-591.

Stamboulis, Y. and Barlas, A. (2014), "Entrepreneurship education impact on student attitudes", The International Journal of Management Education, Vol. 12 No. 3, pp. 365-373.

Stuart, E.A. and Rubin, D.B. (2008), "Best Practices in Quasi-Experimental Designs: Matching Methods for Causal Inference", in Osborne, J. (Ed.), Best Practices in Quantitative Methods, SAGE Publications, Inc., California, pp. 155-176.

Tabachnick, B.G. and Fidell, L.S. (2013), Using Multivariate Statistics, 6th ed., Boston: Pearson Education.

Trochim, W.M.K., Donnelly, J.P. and Arora, K. (2016), Research Methods: The Essential Knowledge Base, 2nd ed., Cengage Learning, available at: https://www.cengage.co.uk/books/9781133954774/ (accessed 22 July 2018).

Unger, J.M., Rauch, A., Frese, M. and Rosenbusch, N. (2011), "Human capital and entrepreneurial success: A meta-analytical review", Journal of Business Venturing, Vol. 26 No. 3, pp. 341-358.

Urbano, D., Aparicio, S., Guerrero, M., Noguera, M. and Torrent-Sellens, J. (2017), "Institutional determinants of student employer entrepreneurs at Catalan universities", Technological Forecasting and Social Change, North-Holland, Vol. 123, pp. 271-282.

Veciana, J.M., Aponte, M. and Urbano, D. (2005), "University Students' Attitudes Towards Entrepreneurship: A Two Countries Comparison", The International Entrepreneurship and Management Journal, Kluwer Academic Publishers, Vol. 1 No. 2, pp. 165-182.

Volery, T., Müller, S., Oser, F., Naepflin, C. and del Rey, N. (2013), "The Impact of Entrepreneurship Education on Human Capital at Upper-Secondary Level", Journal of Small Business Management, John Wiley \& Sons, Ltd (10.1111), Vol. 51 No. 3, pp. 429-446.

Westhead, P. and Solesvik, M.Z. (2016), "Entrepreneurship education and entrepreneurial intention: Do female students benefit?", International Small Business Journal, SAGE PublicationsSage UK: London, England, Vol. 34 No. 8, pp. 979-1003.

Wilson, F., Kickul, J. and Marlino, D. (2007), "Gender, Entrepreneurial Self-Efficacy, and Entrepreneurial Career Intentions: Implications for Entrepreneurship Education", Entrepreneurship Theory and Practice, Wiley/Blackwell (10.1111), Vol. 31 No. 3, pp. 387-406.

van der Zwan, P., Thurik, R., Verheul, I. and Hessels, J. (2016), "Factors influencing the entrepreneurial engagement of opportunity and necessity entrepreneurs", Eurasian Business Review, Springer International Publishing, Vol. 6 No. 3, pp. 273-295. 
